\title{
Leeds-Keio補強用メッシュによる膝前十字勒帯 再建術の治療成績とその問題点について
}

鹿児島前田病院整形外科
松 永 俊 二・貴 島

\author{
Clinical Results and Problems of \\ Anterior Cruciate Ligament Reconstruction \\ Using the Leeds-Keio Artificial Ligament \\ by \\ Shunji Matsunaga and Minoru Kijima \\ Maeda Hospital, Kagoshima, Japan \\ Takashi Sakou, Shinji Tanaka, Yukari Nishi \\ and Kosei Ijiri \\ Department Orthopaedic Surgery, Faculty of Medicine, \\ Kagoshima University, Kagoshima, Japan
}

The clinical results and problems of anterior criciate ligament reconstruction using the Leeds-Keio artificial ligament in a series of 28 patients who desired to participate in sports and vigorous labor were reviewed a mean of sixteen months after surgery.

Nineteen $(68 \%)$ of the 28 could almost completely return to their desired activities after surgery. Lachman's test was positive in ten cases even after surgery. Although we placed the substitute at the isometric point with a special instrument (isometric positioner), Lachman's test changed into positive in eight cases with further flexion beyond 130 degrees. The cause of failure was suspected to be the lack of the elasticity of the substitute.

This procedure should be done with the correct knowledge about the problems of the artificial ligament.

\section{は じめに}

膝関節前十字勒帯損傷患者におけるスポーツおよび 肉体労働上の機能障害に対する治療は, 数多くの手術 法が報告されているものの ${ }^{5)}$ 6) 必ずしも良好な成績が 得られているとは限らず，いまだ問題を残している.

われわれは1985年より，本症に対して Leeds-Keio 補強用メッシュを用い鏡視下前十字勒帯再建術を施行 している. 今回はその術後成績と問題点について検討 し多少の知見を得たので報告する.

\section{対象及び方法}

対象症例は, 陳旧性前十字勒帯損傷患者25名, 新鮮 損傷患者 3 名の計28名であり，いずれも単独損傷例で ある．性別では男性18名女性10名であり，手術時年令 は16才より49才の平均 27 才である. 術後の経過期間は 10ケ月より 27 ケの平均16ケ月である。患者の内訳は バレーボール, ラグビー等のスポーツ選手が19名, 自 衛隊隊員，土木業等の肉体労働者が 9 名であり，いず れもこれらの活動に支障をきたし，今後復帰を望む患 者である. 
前十字鞄帯損傷に合併した半月板損傷は，25例34半 月板であり，半月板は可及的に修復し温存するように 努めた。

前十字勒帯は，再建材料として Leeds-Keio 補強用 メッシュを用い鏡視下に再建した．以前は，直接 $5 \mathrm{~mm}$ のリーマーを用いて骨トンネルを作成し，isometricity の測定をしていたが，これでは測定誤差が大きく適切 な isometric pointの決定は不可能であった。そこで, 現在は2.4 mmのキュルシュナー鋼線を大腿骨側は顆間 部後上方, 脛骨側は勒帯付着部前内方に通している. この骨孔にタイクロン 5 号系を通し, isometric positoner ${ }^{4)}$ に接続し excursion が膝屈曲 $0^{\circ}$ より $120^{\circ}$ で $2 \mathrm{~mm}$ 以内になることを確認し, isometric point を決 定している． isometricとならない場合は，parallel guide を用いて再度キュルシュナー鋼線を入れ直し isometric pointを見つけ出している.この新しい方 法によって isometricity を確認した症例は28例中19例 である。

Isometric pointの確認が終わるとリーマーにて骨 トンネルを作成し，ここに人工勒帯を通しさらに関節 外補強を加えている.

術後成績の評価は日常生活動作およびスポーツ肉体 労働への復帰度を中心とした患者の主観的な満足度, および他覚的評価として前方引き出しテスト, Lachman テスト，Jerkテストの有無等を調べることにより評 価した。

\section{結}

\section{果}

主観的満足度でみると，日常生活動作上の障害は術 前 $43 \%$ から術後 $7 \%$ と改善をみているが，目的とする スポーツ，肉体労働への復帰度をみると，術前は全例 支障をきたしていたが，術後80\%以上のレベルまで復 帰出来たものは全体の68\%であった。復帰に支障をき たしている 9 例中, Jerk テストが陽性のものは 3 例の みであり残りの 6 例は以前経験した giving way への 恐怖心のため復帰が出来ないという状態のものであっ た.

他覚的所見では前方引き出しテストは術後全例消失 したが, Lachman テストは10例に術後も認められた。 また，Jerkテストは 3 例に術後も残存していた.

術後 Lachman 陽性10例のうち, isometric posioner を用い正確に術中 isometricity を測定出来た 6 例の測
定結果では， 6 例中 1 例はどうしても isometric point が見出せなかったが, 残りの 5 例は, いずれも0〜120 度に於いて $2 \mathrm{~mm}$ 以内の Excursion におさまっており 術中はisometric pointに鞄帯を作成出来たと判定し た（図1).

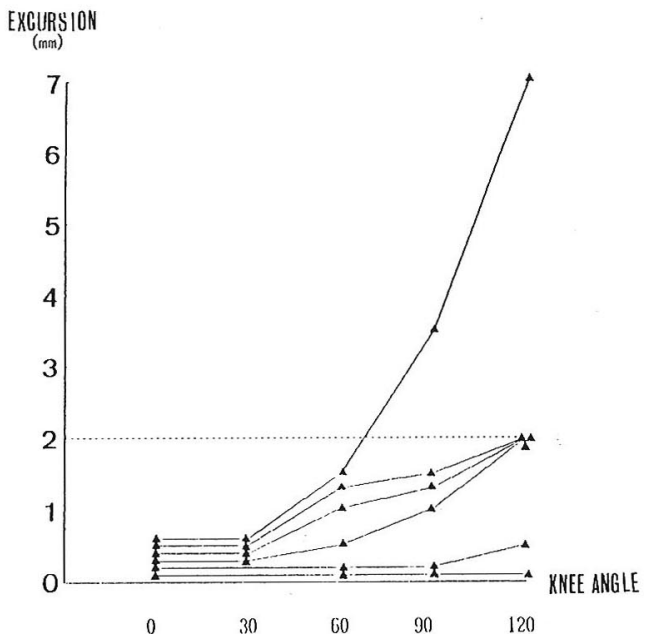

図 1 術後 Lachman テスト陽性例の術中 isometricity (Isometric positioner 使用 6 例について)

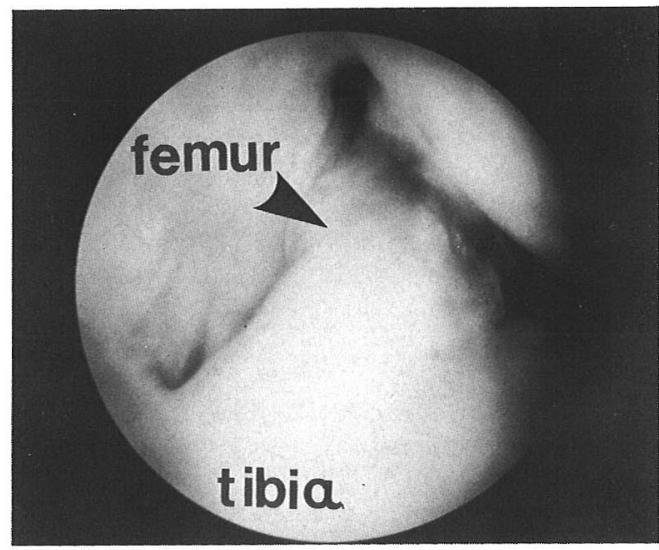

図 2 術後 1 年の関節鏡所見 勒帯様組織 (矢印)の再生が認められるが, 正常 な血管走行は全く認められない。

Lachman 陽性10例についてさらに術後の膝可動域 と Lachman 陽性の有無との関係をみると, isometric positioner を使用せず正確な isometricity の測定をし ていない 2 例は, 屈曲125度の時点で Lachman 陽性と 
なっているが, 残りの 8 例は，いずれも膝可動域が 130 度以上になった時点で，陰性から陽性へ悪化して いた。

28 例中 4 例に, 術後 1 年以上経過した時点で再度関 節鏡検査を施行し，再建勒帯の状態を確認することが できた. 4 例とも勒帯様組織ができているが血管はま ったく認められず，生理的勒帯への置換に疑問を抱か せた（図 2 )。

\section{考察}

人工勒帯による前十字勒带再建術には，いくつかの 問題点が残されている.

まず，その elasticityの問題であるが，術後膝 $130^{\circ}$ 以上でLachman テストが陽性になった原因として， 勒帯の骨内固定部位からの引き出しとも考えられるが, 人工勒帯そのものの elasticity の欠如による可能性も ある。

つぎに，人工勒帯か確実に生理的勒帯に置換される か否かについてであるが，図2に示したような症例も あり，また，再生した鞄帯は組織学的には正常なコラ 一ゲン線維の配列はなく，勒帯としての機能は不十分 であるとする報告 ${ }^{1} も$ もりまだ問題が残る.

この点から考えても人工勒帯を isometric な位置に 再建することは非常に重要である3)が，実際は，isometric point を正しく決定するのは容易ではなく不適 切な位置に作成されることが多い，われわれは，この 点を改善すべく isometric positioner を使用し, 術中 isometricity を測定した。

以上，人工勒帯による前十字勒帯再建術は自家組織 を犠牲にしないこと，および復帰の早さの利点から， スポーツ肉体労働者に適した手術である ${ }^{2)}$ が，人工勒 帯ゆえの問題点を十分認識して行う必要があり，特に， 術後 130 度以上の膝屈曲については, 注意を要すと考 える.

結語

1. 受傷前の80\%以上のレベルまで復帰できたものは,
28例19例の68\%であった.

2. Leeds-Keio 補強用メッシュが生理的勒帯に置換 されるか否かについては今後の研究課題である.

3. 本術式には isometric positioner を使用し, 正確 に isometric point を求めることが大切である.

4. 術後の膝屈曲角度は 130 度までを目標とする.

\section{参 考 文 献}

1) Arnozky, S.P., et al.: Replacement of the anterior cruciate ligament using a synthetic prosthesis. An evaluation of graft biology in the dog. Am. J.Sports Med., 14:1-6, 1986.

2）富士川恭輔，ほか：Leeds-Keio 人工膝関節勒帯に よる前十字勒帯再建術法について. 整形外科, 35 ： 879-887, 1984.

3）富士川恭輔，ほか：膝関節前十字勒帯再建術におけ る substituteの固定部位と固定時の膝関節角度につい て. 膝, $9:$ 134-139, 1984.

4) Jackson, D. and Drez, D.: The anterior cruciate deficient knee. Mosby, St. Luvis, 1987.

5) Johnson, R.J et al.: Five to ten-year follow-up evaluation after reconstruction of the anterior cruciate ligament. Clin. Orthop., 183:122-140, 1984

6) 高橋秀裕, ほか：膝関節内前十字勒帯再建術 (Jones 法）の遠隔成績. 臨床整形外科, $17: 856-863,1982$.

質 問山口大学 松岡 彰 骨孔の abrasion は行なっていますか.

解 答前田病院 松永 俊二 再建勒帯のAbration を生じさせないという意味か らしても isometric な部位に勒帯をつくることが大切 だと思う。

先生のような方法で Abration 防止対策は特にやっ ていないが現在までのところ Abration 自体によると 思われるトラブルは生じていない. 